\title{
Peningkatkan Hasil Belajar Matematika dan Kemampuan PemecahanMasalah Siswa SMA Melalui Pendekatan Saintifik
}

\author{
Ayu Rahmayanti ${ }^{1}$ \\ Basuki Wibawa $^{2}$ \\ Khaerudin $^{3}$
}

\begin{abstract}
Abstrak: Penelitian tindakan ini mengangkat tentang peningkatkan kemampuan pemecahan masalah dan hasil belajar matematika melalui pendekatan saintifik. Penelitian ini dilaksanakan di SMAN 6 Takalar, bekerjasama dengan guru mata pejaran untuk memberikan tindakan (proses pembelajaran dengan pendekatan saintifik). Penelitian tindakan ini dilaksanakan pada semester genap, tahun ajaran 2017/2018. Sebelumnya peneliti telah melakukan studi pendahuluan mulai bulan September 2015.Manfaat penelitian ini adalah dapat memecahkan berbagai permasalahan yang ada.Secara khusus, untuk: (1) Meningkatkan kemampuan pemecahan masalah siswa melalui pendekatan saintifik (2) Meningkatkan hasil belajar matematika siswamelalui pendekatan saintifik.Hasil penelitian menunjukkan bahwapenerapan pendekatan saintifikdapat meningkatkan hasil belajar matematika dan kemampuan pemecahan masalah siswa di SMAN 6 Takalar.
\end{abstract}

Keyword: Action research, pendekatan saintifik, hasil belajar matematika, kemampuan pemecahan masalah

\begin{abstract}
This action research raises about improving problem solving abilities and mathematics learning outcomes through the scientific approach. This research was conducted at SMAN 6 Takalar, in collaboration with eye instructor teachers to provide action (learning process with scientific approach). This action research was conducted on even semester, academic year 2017 / 2018. Previous researchers have conducted a preliminary study starting in September 2015.The benefits of this study were able to solve various problems that exist. In particular, to: (1) Improve student problem solving ability through scientific approach, (2) Increase student learning outcomes through scientific approach. The results showed that the application of the scientific approach can improve mathematics learning outcomes and problem solving abilities of students at SMAN 6 Takalar.
\end{abstract}

Keyword: Action research, scientific approach, mathematics learning outcomes, problem solving ability

${ }^{1}$ Ayu Rahmayanti, Universitas Negeri Jakarta, e-mail:ayurahmayantitp14s3@mahasiswa.inj.ac.id. HP. 082310080909

${ }^{2}$ Basuki Wibawa, Fakultas Teknik, Universitas Negeri Jakarta, e-mail: basukiwibawa@unj.ac.id. HP. 0818752448

${ }^{3}$ Khaerudin, Fakultas Ilmu Pendidikan, Universitas Negeri Jakarta, e-mail:

khaerudin.psb@gmail.com.HP.08161189108 


\section{PENDAHULUAN}

Dewasa ini, kemajuan dalam berbagai bidang menuntut tersedianya Sumber Daya Manusia yang bermutu. Pendidikan dicanangkan sebagai suatu jalan efektif agar terciptanya Sumber Daya Manuasia (SDM) yang bermutu tersebut. Berbagai upaya telah dilakukan oleh pemerintah dalam rangka mendukung peningkatkan dan menjaga mutu pendidikan nasional. Undang Undang No.20 tahun 2003 tentang Sistem Pendidikan Nasional dan Peraturan Pemerintah No.19 Tahun 2005 tentang Standar Nasional Pendidikan (SNP) adalah beberapa wujud perhatian pemerintah terhadap pendidikan nasional yang dituangkan dalam bentuk kebijakan nasional. Akan tetapi kebijakan nasional tersebut tidak akan berarti jika penerapannya dilapangan tidak sejalan ataupun tidak mengarah pada prinsip kebijakan nasional tersebut.

Pendidikan nasional berfungsi mengembangkan kemampuan dan membentuk watak serta peradaban bangsa yang bermartabat dalam rangka mencerdaskan kehidupan bangsa, bertujuan untuk berkembangnya potensi peserta didik agar menjadi manusia yang bermartabat dalam rangka mencerdaskan kehidupan bangsa, bertujuan untuk berkembangnya potensi peserta didik agar menjadi manusia yang beriman, dan bertakwa kepada Tuhan yang Maha Esa, berakhlak mulia, sehat, berilmu, cakap, kreatif, mandiri, dan menjadi warga Negara yang demokratis serta bertanggung jawab. Dapat disimpulkan bahwa inti dari tujuan pendidikan adalah terciptanya Sumber Daya Manusia (SDM) yang bermutu.
Sekolah tentunya menjadi tempat utama penerarapan berbagai kebijakan nasional pendidikan yang telah ditetapkan oleh pemerintah. Sekolah adalah lembaga pendidikan yang secara resmi menyelenggarakan kegiatan pembelajaran secara sistematis, terencana, dan terarah. Mulai dari tingkattaman kanak-kanak sampai dengan perguruan tinggi. Matematika merupakan salah satu mata pelajaran yang diajarkan pada setiap jenjang pendidikan dan juga merupakan salah satu mata pelajaran yang diikut sertakan dalam ujian nasional. Akan tetapi nilai hasil belajar siswa pada mata pelajaran ini masih cukup memperihatinkan. Menurut hasil penilaian yang dilakukan oleh tim PISA (Programme for International Students Assessment) pada bidang matematika, di tahun 2015 Indonesia berada pada ranking ke 63 dari 70 negara yang berpartisipasi (dapat dilihat pada gambar 1.1). Pada penilaian sebelumnya di tahun 2012 Indonesia berada pada ranking ke 64 dari 65 negara yang berpartisipasi (OECD, 2015). Walaupun ranking Indonesia mengalami peningkatan, akan tetapi capaian siswa Indonesia pada Programme for International Students Assessment (PISA) tetap masih memprihatinkan. Rendahnya hasil capaian peserta didik Indonesia pada hasil pengukuran yang dilakukan oleh PISA mencerminkan rendahnya kemampuan peserta didik dalam komponen proses, khususnya pada kemampuan pemecahan masalah.

Kemampuan pemecahan masalah juga merupakan keterampilan yang harus dimiliki dalam konteks abad ke-21. Agran bahkan melakukan penelitian untuk meningkatkan keterampilan pemecahan masalah siswa disabilitas (Agran, 2002). 
Berdasarkan pengamatan awal yang telah dilakukan di SMA Negeri 6 Takalar, diperoleh data bahwa rata-rata nilai akhir hasil belajar peserta didik pada mata pelajaran matematika masih dibawah angka 7,50 (kriteria ketuntasan minimal). Diuraikan pada tabel 2.1, dapat dilihat bahwa walaupun rata-rata nilai sekolah siswa telah memenuhi kriteria ketuntasan minimal, namun rata-rata nilai ujian nasional dan nilai akhir siswa masih di bawah kriteria ketuntasan minimal. Ada banyak faktor yang menjadi penyebab rendahnya nilai hasil belajar matematika dan kemampuan pemecahan masalah siswa di sekolah. Berdasarkan hasil wawancara terhadap guru mata pelajaran diperoleh informasi bahwa rendahnya hasil belajar matematika peserta didik disebabkan oleh kurangnya pemahaman siswa terhadap apa yang telah dibelajarkan. Sementara menurut hasil wawancara kepada beberapa siswa, kebanyakan dari mereka menganggap mata pelajaran matematika sebagai mata pelajaran yang mengerikan, membosankan, dan sulit untuk dipahami sehingga hal tersebut mempengaruhi proses pembelajaran matematika siswa. Oleh sebab itu, dibutuhkan pendekatan pembelajaran yang memacu proses berpikir siswa dan tidak membiarkan siswa terpaku pada opini yang negatif tentang mata pelajaran matematika.

Selain itu diperlukan pula guru yang kompeten untuk dapat menghasilkan hasil belajar siswa yang maksimal. Ada empat strategi pengembangan kompetensi guru yang dapat dijadikan alternatif pengembangan ke depan, yaitu (1) peningkatan kompetensi melalui pengembangan tatap muka dalam bentuk professional courses, (2) peningkatan melalui konsep blended learning serta e-training, (3) peningkatan melalui kegitan diseminasi dan bahan ajar, dan (4) peningkatan melalui komunitas belajar professional (Wibawa, 2017: 59).

Pemilihan pendekatan, model, strategi yang digunakan sangat mempengaruhi proses dan hasil belajar peserta didik. Khususnya untuk mata pelajaran matematika yang bersifat abstrak dan memiliki persepsi awal yang kurang baik bagi siswa. Pemerintah terusmenerus melakukan pembenahan dalam merancang serta menyusun kurikulum pendidikan nasional, dan K13 merupakan inovasi pemerintah sebagai upaya meningkatakan mutu pendidikan nasional.

K13 menawarkan penerapan pendekatan saintifik dalam proses pembelajaran, khususnya bagi mata pelajaran matematika.Proses pembelajaran dengan menerapkan pendekatansaintifik adalah proses pembelajaran yang mengadopsi langkah-langkah ilmiah dalam prosesnya.Dalam pendekatan saintifik, materi pembelajaran berbasis pada fakta atau fenomena yang dapat dijelaskan dengan logika atau penalaran tertentu dan mendorong serta menginspirasi siswa berpikir secara kritis, analitis, dan tepat dalam mengidentifikasi, memahami, memecahkan masalah, dan mengaplikasikan materi pembelajaran.

Menurut Barrier, et al. dalam Abidin pembelajaran proses saintifik merupakan pembelajaran yang menuntut siswa berpikir secara sistematis, dan kritis dalam upaya memecahkan masalah yang penyelesaiannya tidak mudah dilihat. Selain itu, proses pembelajarannya yang sistematis juga sangat tepat digunakan untuk mata pelajaran matematika yang bersifat abstrak (Abidin, 2013:125). Oleh karena itu, penerapan pendekatan saintifik dalam proses pembelajaran 
dapat meningkatkan kemampuan pemecahan masalah siswa.

Berdasarkan hasil penelitian yang dilakukan oleh Huwono yang berjudul Pengaruh Pendekatan Saintifik terhadap Hasil Belajar Siswa pada Pelajaran Fisika Materi Hukum Gerak Newton Kelas X SMA Negeri 1 Telaga, diperoleh skor hasil belajar siswa untuk kelas yang menggunakan pendekatan saintifik memiliki nilai rata-rata lebih tinggi dibandingkan dengan kelas yang menggunakan masalah kognitif. Mata pelajaran matematika dan fisika merupakan mata pelajaran sains yang memiliki banyak persamaan, sehingga jika penerapan pendekatan saintifik pada mata pelajaran fisika menghasilkan pengaruh yang positif maka dimungkinkan pada mata pelajaran matematika dapat pula memberikan pengaruh dalam meningkatkan hasil belajar siswa (Huwono, 2014:1).

Kite mengemukakan bahwa kegiatan saintifik memiliki kontribusi yang sangat penting dalam menciptakan totalitas pendidikan siswa. Selain itu, langkah-langkah saintifik juga membantu siswa dengan kesulitan belajar untuk mengatur pikiran mereka (Kite, 2018).

Penelitian yang dilakukan oleh Tatsunori Matsui dengan judul "Discovery Scientific Approach to Extraction Produce of Educational Procedure of Educational Meaningful Information from Learning History Data". Matsui mengemukakan bahwa dengan penerapan pendekatan saintifik, informasi yang diperoleh menjadi lebih bermakna (Matsui, 2002). Penelitian yang dilakukan oleh Tolmie dengan judul "Understanding Core Skills and Influences in Primary School Science Learning: Taking a Scientific Approach". Pada hasil penelitiannya
Andy mengemukakan pentingnya pendekatan saintifik dalam pembelajaran dan desain kurikulum (Tolmie, 2012).

Melihat berbagai fenomena diatas, maka perlu dilakukan suatu upaya untuk dapat meningkatkan kemampuan pemecahan masalah dan juga hasil belajar matematika siswa. Penilaian hasil belajar matematika erat kaitannya dengan penilaian dalam ranah kognitif. Berkaitan dengan ini, Anne Jordan menuliskan "cognitivism presents a scientific approach to learning and offers a coherent understanding of the processes involved" (Jordan, 2008:51). Oleh sebab itu, pendekatan saintifik sebagai salah satu pendekatan yang ditawarkan dalam K13 diharapkan dapat menjadi solusi yang tepat dalam upaya meningkatakan hasil belajar dan kemampuan pemecahan masalah siswa.

Action research is a systematic approach to investigation that enables people to find effective solutions to problems they confront in their everyday lives. Action research is a collaborative approach to inquiry or investigation that provides people with the means to take systematic action to resolve specific problems (Stringer, 2007:1,8).

Penelitian tindakan menjadi solusi yang tepat dalam suatu pemecahan masalah, karena menawarkan pendekatan yang sistematis dalam langkah-langkah pelaksanaannya. Pelaksanaan tindakan dengan langkah yang sistematis tersebut memungkinkan terjadinya tindakan dengan proses dan hasil yang lebih efektif dan efisien.

Penelitian tindakan (action research) atau disingkat AR ditandai dengan pendekatan systematic inquiry yang memiliki ciri, prinsip, pedoman, prosedur yang harus memenuhi kriteria tertentu. Pendekatan systematic inquiry adalah 
pendekatan yang menekankan pada proses mencari dan menemukan. Adanya penekanan pada pendekatan systematic inquirydalam penelitian tindakan ini menjadikan penelitian tindakan sebuah penelitian yang memerlukan usaha maksimal dalam pelaksanaannya (Yaumi, 2014:3)

Terdapat dua kata kunci yang satu di antaranya harus ada pada setiap kegiatan action research, yaitu pemecahan masalah (problem solving), dan peningkatan (improving) kinerja system (Mulyas, 2008:152). Penelitian tindakan berangkat dari dua hal, yaitu pemecahan masalah dan peningkatan. Penelitian tindakan merupakan suatu langkah yang diambil guna mencari solusi dari sebuah masalah. Penelitian tindakan juga dilakukan sebagai upaya peningkatan suatu prestasi kerja.

Jika dibandingkan dengan penellitian lain, penelitian tindakan sudah lebih jauh ke depan. Penelitian tindakan bukan lagi mengetes sebuah perlakuan, tetapi sudah mempunyai keyakinan akan ampuhnya sesuatu perlakuan (Arikunto, 2010:26). Persamaan penelitian tindakan dengan penelitian eksperimen adalah dalam pelaksanaan kedua jenis penelitian tersebut sama-sama terdapat treatment (perlakuan/tindakan). Akan tetapi penelitian eksperimen dilakukan untuk menguji suatu treatment, sedangkan dalam penelitian tindakan treatment yang digunakan adalah tindakan/perlakuan yang sudah diyakini keampuhannya.

Belajar adalah serangkaian kegiatan jiwa raga untuk memperoleh suatu perubahan tingkah laku sebagai hasil dari pengalaman individu dalam interaksi dengan lingkunganya yang menyangkut kognitif, afektif, dan psikomotor
(Djamarah, 2013:11). Belajar adalah proses perubahan tingkah laku sebagai akibat adanya interaksi antara individu dengan lingkungannya.

Belajar memberikan pengalaman dan pemahaman yang baru bagi individu sebagai hasil dari proses yang telah dijalani. Belajar bukan hanya dipandang sebagai suatu proses ataupun kegiatan yang bersifat hapalan, tapi belajar harus memberikan suatu perubahan. Belajar sebagai proses interaksi individu dengan lingkungannya harus menghasilkan perubahan bagi individu, baik pada aspek kognitif, afektif, dan psikomotor.

Kimble mendefinisikan belajar sebagai perubahan yang relatif permanen di dalam behavioral potentiality (potensi behavioral) yang terjadi sebagai akibat dari reinforced practice (praktik yang diperkuat) (Hergenant, 2015:2). Agar hasil dari belajar dapat bersifat permanen maka perlu diperkuat dengan adanya pengulangan, baik dengan teori ataupun praktik.

Kata "matematika" berasal dari kata mathema dalam bahasa Yunani yang diartikan sebagai "sains, ilmu pengetahuan, atau belajar". Juga mathematikos yang diartikan sebagai "suka belajar" (Sriyanto, 2007:12).

Matematika adalah bahasa yang melambangkan serangkaian makna dari pernyataan yang ingin kita sampaikan. Lambanglambang matematika bersiffat "artifisial" yang baru mempunyai arti setelah sebuah makna diberikan padanya. Lebih lanjut Jujun juga mengemukakan bahwa bagi dunia keilmuan matematika berperan sebagai bahasa simbolik yang memungkinkan terwujudnya komunikasi yang cermat dan tepat (Jujun, 2010:190).

Jadi jika dilihat dari pengertian matematika menurut bahasa, matematika itu sendiri berarti 
belajar atau suka belajar. Matematika adalah ilmu pengetahuan. Akan tetapi matematika juga berfungsi sebagai alat komunikasi. Matematika merupakan bahasa simbolik yang dapat digunakan untuk menyapaikan suatu komunikasi yang cermat dan tepat. Matematika membantu menyampaikan pesan dengan jelas, karena ada beberapa hal yang abstrak kejelasannya jika disampaikan tanpa penggunaan simbol matematika. Misalnya saja hal-hal yang berkaitan dengan jarak dan jumlah, semua hal ini tidak akan jelas jika tidak diungkapkan melalui symbolsimbol matematika.

Hasil belajar dapat dijelaskan dengan memahami dua kata yang membentuknya, yaitu "hasil" dan "belajar". Pengertian hasil (product) menunjukkan pada suatu perolehan akibat dilakukannya suatu aktivitas atau proses yang mengakibatkan berubahnya input secara fungsional. Dalam siklus input-prose-hasil, hasil dapat dengan jelas dibedakan dengan input akibat perubahan oleh proses. Begitu pula dalam kegiatan belajar mengajar, setelah mengalami belajar siswa berubah perilakunya dibanding sebelumnya (Purwanto, 2010:44).

Belajar menghasilkan suatu perubahan pada siswa; perubahan itu dapat berupa pengetahuan, pemahaman, keterampilan, dan sikap. Perubahan itu merupakan hasil dari usaha belajar yang tersimpan dalam ingatan (Winkel, 2014:84)

Hasil belajar melahirkan peserta didik yang produktif, kreatif, inovatif, dan afektif melalui penguatan sikap, keterampilan, dan pengetahuan yang terintegritas (Hosnan: 2014:33). Hasil belajar adalah kemampuan-kemampuan yang dimiliki siswa setelah ia menerima pengalaman belajarnya (Sujana, 2011:22).

Pandangan lain tentang masalah dalam pembelajaran dinayatakan sebagai a problem is a situation in which you are trying to reach some goal, and must find a means for getting there (T.H. Chi,2016: 227). Masalah adalah suatu keadaan yang harus dipecahkan. Masalah adalah suatu keadaan dimana kita mencoba untuk mencapai suatu tujuan, dan harus menemukan cara untuk mencapai tujuan tersebut.

Chatib mengemukakakn bahwa problem solving adalah salah satu sumber kecerdasan anak. Ia meyakini bahwa proses problem solving adalah proses menuju kecerdasan. Anak memperoleh pengetahuan dari proses problem solving yang ia lakukan (Chatib, 2013: 113).

Hal serupa juga dikemukakan oleh Howe dalam Gredler, belajar berbicara dan mengerti bahasa pertama, mengenali wajah, terlibat dalam interaksi sosial, dan melakukan teknik pemecahan masalah umum merupakan keterampilan yang diperoleh anak dari pengalaman sehari-hari (Gredler, 2011:273).

Lebih lanjut Chi dan Glaser mengemukakan bahwa solving problems is a complex cognitive skill that characterizes one of the most intelligent human activities. Dari pernyataan tersebut kita dapat mengambil dua kesimpulan, yaitu: (1) Pemecahan masalah adalah kemampuan dalam ranah kognitif, dan (2) Pemecahan masalah adalah kemampuan intelegensi tingkat tinggi (T. H. Chi,2016: 227).

Akinmola mengemukakan pentingnya memperhatikan lima komponen penting dalam pembelajaran matematika, terutama memperhatikan kemampuan pemecahan masalah 
siswa. Hal ini dikarenakan kemampuan pemecahan masalah termasuk dalam 2 komponen dari lima komponen yang ada. Maka pengembangan kemampuan pemecahan masalah siswa sangatlah penting. Selain itu, Akinmola juga menjelaskan bahwa untuk mengembangkan kemampuan pemecahan masalah siswa maka diperlukan kurikulum, metode pengajaran, dan penilaian yang berpusat pada siswa (Akinmola, 2014: 3).

Woods mengemukakan hasil penemuannya bahwa siswa membutuhkan pemahaman yang baik terkait pelajaran yang ada dan juga keterampilan pemecahan masalah umum untuk menyelesaikan masalah dengan sukses (Woods, 2013:86). Lebih lanjut Richard mengemukakan bahwa peran keterampilan kognitif, metakognitif, dan motivasi dalam pemecahan masalah saling berkaitan. Keterampilan kognitif termasuk tujuan instruksional, komponen dalam hirarki pembelajaran, dan komponen dalam pemrosesan informasi. Keterampilan metakognitif termasuk strategi untuk membaca pemahaman, menulis, dan matematika. Keterampilan motivasi termasuk motivasi berdasarkan minat, self-efficacy, dan atribusi. Ketiga jenis keterampilan tersebut diperlukan untuk memecahkan masalah dalam pembelajaran (Mayer, 1998: 46).

\section{METODE PENELITIAN}

Penelitian ini dilaksanakan di SMA Negeri6 Takalar. Penelitian tindakan ini dilaksanakan pada semester genap, tahun ajaran 2017/2018. Sebelumnya peneliti telah melakukan studi pendahuluan mulai bulan September 2015.
Metode penelitian yang digunakan dalam penelitian ini adalah action research. Ada tiga sifat penelitian action research, yaitu proaktif, reaktif, dan menemukan. Proaktif lebih banyak bersifat pengembangan, atau sering dianggap penelitian pengembangan. Bersifat reaktif yaitu memperbaikai hal yang semula dianggap kurang.

Penelitian ini adalah penelitian reaktif yaitu untuk memperbaiki sesuatu yang sebelumnya dianggap kurang. Model yang dipilih dalam riset tindakan ini adalah Kemmis dan Taggart yang digambarkan dalam model spiral sebagai berikut:

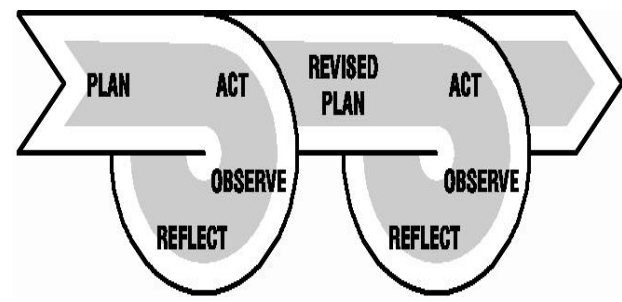

\section{Gambar 3.1 Model Penelitian Tindakan} Kemmis dan Taggart

\section{HASIL PENELITIAN DAN PEMBAHASAN}

\section{Siklus I}

Kegiatan-kegiatan yang dilaksanakan pada siklus I adalah sebagai berikut:

a). Perencanaan, setelah melakukan pengamatan awal, peneliti menetapkan tiga permasalahan yang perlu segera diperbaiki, yaitu (1) kemampuan pemecahan masalah siswa rendah, (2) hasil belajar kognitif siswa rendah (3) hasil belajar afektif siswa rendah. Berdasarkan permasalahan yang ada, maka peneliti menyusun rencana pelaksanaan tindakan siklus I untuk meningkatkan hasil belajar matematika dan kemampuan pemecahan masalah siswa dengan penerapan pendekatan saintifik dalam pembelajaran. Adapun rencana pelaksanaan tindakan pada siklus I adalah sebagai berikut: (1) menjabarkan hasil pengamatan awal; 
(2) membuat rencana pelaksanaan pembelajaran (RPP) yang menggunakan pendekatan saintifik; menyusun bahan ajar;

membuat/menyediakan media pembelajaran; (5) membuat pedoman observasi; (6) membuat pedoman wawancara guru dan siswa; (7) membuat instrumen tes untuk mengukur kemampuan pemecahan masalah dan hasil belajar matematika siswa.

b) Pelaksanaan, penelitian tindakan pada siklus I dilaksanakan pada tanggal 31 Januarisampai tanggal 10 Februari 2018 di SMAN 6 TAKALAR. Penelitian pada Siklus I ini dilaksanakan dengan empat kali pertemuan dengan waktu 2 x 45 menit untuk setiap pertemuan. Pelaksanaan tindakan ini diawali dengan pelatihan penerapan pendekatan saintifik kepada para guru di sekolah tersebut. Penerapan pendekatan saintifik dalam pembelajaran untuk meningkatkan hasil belajar matematika dan kemampuan pemecahan masalah siswa terdiri dari langkah-langkah sebagai berikut: (1) mengamati, aktivitas belajar yang terjadi pada tahap ini adalah melihat, mengamati, membaca, mendengar, dan menyimak (tanpa dan dengan alat). Pada tahap ini guru menyajikan beberapa data yang berkaitan dengan materi yang akan diajarkan dan mengarahkan siswa agar menggunakan seluruh panca indra yang dimilikinya untuk mengamati informasiinformasi yang terkait dengan materi yang diajarkan; (2) menanya, bertanya merupakan salah satu pintu masuk untuk memperoleh pengetahuan. Pada tahap kedua ini siswa dipersilahkan untuk mengajukan pertanyaan dari yang faktual sampai ke yang bersifat hipotesis.
Diawali dengan bimbingan dari guru sampai dengan mandiri (menjadi suatu kebiasaan). Pada tahap ini siswa diarahkan untuk mengajukan pertanyaan tentang informasi yang tidak dipahami dari apa yang telah diamati pada tahap sebelumnya atau pertanyaan untuk mendapatkan informasi tambahan. Kompetensi yang dikembangkan adalah kreativitas, rasa ingin tahu, dan kemampuan merumuskan pertanyaan; (3) pengumpulan data, pada tahap ini guru mengarahkan siswa untuk menggali dan mengumpulkan informasi dari berbagai sumber melalui berbagai cara. Pengumpulan data dapat dilakukan melalui eksperimen, membaca sumber lain selain buku teks, mengamati objek, kejadian, aktifitas wawancara dengan narasumber, dan sebagainya. Adapun kompetensi yang diharapkan adalah mengembangkan sikap teliti, jujur, sopan, menghargai pendapat orang lain, kemampuan berkomunikasi, menerapkan kemampuan mengumpulkan berbagai informasi melalui berbagai cara yang dipelajari, mengembangkan kebiasaan belajar dan belajar sepanjang hayat; (4) mengasosiasi, mengasosiasi atau associating dapat pula diartikan menalar atau mengolah informasi. Pada tahap ini guru dan siswa diarahkan untuk aktif dalam proses belajar mengajar, tapi tentunya dalam banyak hal dan situasi siswa harus lebih aktif daripada guru. Siswa diminta untuk bernalar, mengasosiasi, mengolah informasi, dan berpikir kreatif. Berpikir secara logis dan sistematis atas fakta-fakta empris yang dapat diobservasi untuk memperoleh simpulan berupa pengetahuan. Siswa diarahkan untuk memproses informasi yang sudah 
disimpulkan, baik dari hasil kegiatan pengumpulan data maupun hasil dari kegiatan mengamati dan kegiatan menanya; mengkomunikasikan, aktifitas belajar yang terjadi pada tahap ini adalah siswa menyampaikan hasil pengamatan, kesimpulan berdasarkan hasil analisis secara lisan, tertulis, atau dalam bentuk lainnya. Pada tahap ini guru memberikan kesempatan pada siswa untuk mengkomunikasikan hasil pekerjaan yang telah mereka susun, baik secara bersama-sama dalam kelompok ataupun secara individu. Setelah itu guru juga memberikan klarifikasi agar siswa mengetahui dengan benar apakah jawaban yang telah dikerjakan sudah benar atau ada yang perlu diperbaiki. Kompetensi yang diharapkan dari tahap ini adalah mengembangkan sikap jujur, teliti, toleransi, kemampuan berpikir sistematis, mengungkapkan pendapat dengan singkap dan jelas, dan mengembangkan kemampuan berbahasa yang baik dan benar.

c). Observasi, observasi dilakukan untuk mengamati proses tindakan yang sedang berlangsung. Kegiatan yang dilakukan selama tahap pengamatan dalam penelitian ini meliputi: (a) memantau tindakan pelaksanaan pembelajaran berdasarkan pendekatan saintifik; (b) mengamati dan mencatat hal-hal yang terjadi pada saat proses pembelajaran berlangsung; (c) mengamati aktivitas siswa, baik secara individu ataupun kelompok salama proses pembelajaran berlangsung; (d) melakukan dokumentasi proses tindakan yang berlangsung.

d) Refleksi, refleksi dilakukan dengan mengkaji dan menilai seluruh data yang diperoleh pada setiap tahap yang telah dilakukan sebagai dasar pengukuran keberhasilan siklus penelitian tindakan. Data diperoleh dari hasil tes hasil belajar matematika, angket sikap kemampuan pecahan masalah, observasi afektif siswa, dan catatan lapangan. Data hasil belajar matematika diperoleh dari hasil tes formatif.

\section{Refleksi Hasil Belajar Matematika Siswa}

Berdasarkan analisis terhadap hasil belajar siswa, maka nilai yang diperoleh siswa siklus I ini belum memenuhi kriteria keberhasilan tindakan dalam penelitian yang dilaksanakan. Peningkatan hasil belajar matematika siswa pada siklus I dapat dilihat pada grafik berikut:

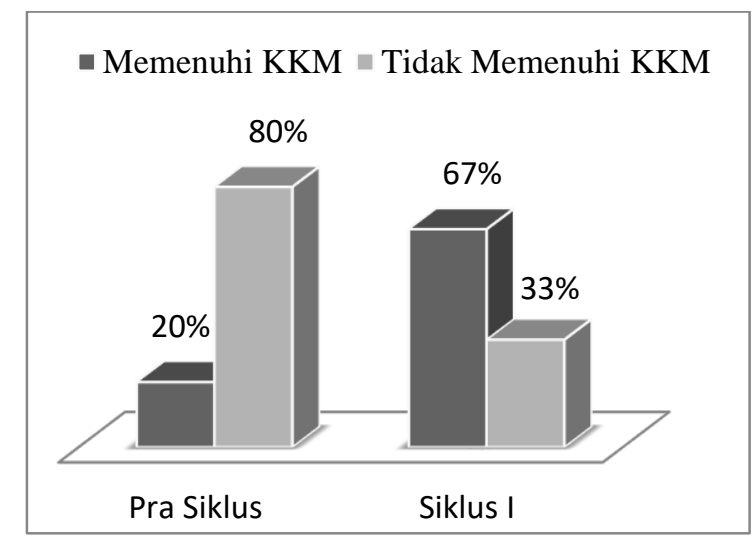

Gambar 4.1 Grafik Peningkatan Hasil Belajar Matematika Siswa Siklus I

Pada pra siklus persentase siswa yang memenuhi nilai KKM adalah 20\% (16 siswa) dan siswa yang tidak memenuhi nilai KKM adalah 80\% (65 siswa). Setelah diberikan tindakan pada siklus I diperoleh persentase siswa yang memenuhi nilai KKM adalah 67\% (54 siswa) dan siswa yang tidak memenuhi nilai KKM adalah 33\% (27 siswa). Terdapat peningkatan pada jumlah siswa yang memenuhi nilai KKM, akan tetapi angka tersebut belum memenuhi kriteria keberhasilan tindakan dalam penelitian ini. 
Jumlah minimal siswa yang memenuhi nilai KKM adalah $75 \%$, barulah tindakan penelitian ini dapat dikatan berhasil. Maka penerapan pendekatan saintifik untuk meningkatkan hasil belajar matematika siswa pada siklus I belum mencapai target yang diinginkan. Adapun refleksi penerapan pendekatan saintifik pada siklus I yaitu: (a) tidak semua siswa aktif dalam proses menanya; (b) siswa tidak berpikiran terbuka dalam menerima pendapat temannya sehingga sulit untuk melaksanakan proses pengumpulan data, mengasosiasi, dan mengkomunikasikan secara optimal; (c) guru kurang tegas dalam mengarahkan siswa; (d) siswa belum memahami dengan baik matematika dasar ataupun materi yang menjadi materi prasyarat dalam materi yang diajarkan. (e) penerapan pendekatan saintifik untuk meningkatkan hasil belajar matematika siswa belum terealisasikan dengan baik sesuai yang direncanakan. Masih ada beberapa hal yang perlu dikoreksi dan diperbaiki.

\section{Refleksi Hasil Angket Kemampuan Pemecahan Masalah Siswa}

Penilaian kemampuan pemecahan masalah siswa diperoleh melalui angket yang diberikan kepada siswa. Hasil yang diperoleh pada siklus I belum memenuhi kriteria keberhasilan tindakan penelitian. Peningkatan kemampuan pemecahan masalah siswa pada siklus I dapat dilihat pada grafik berikut:

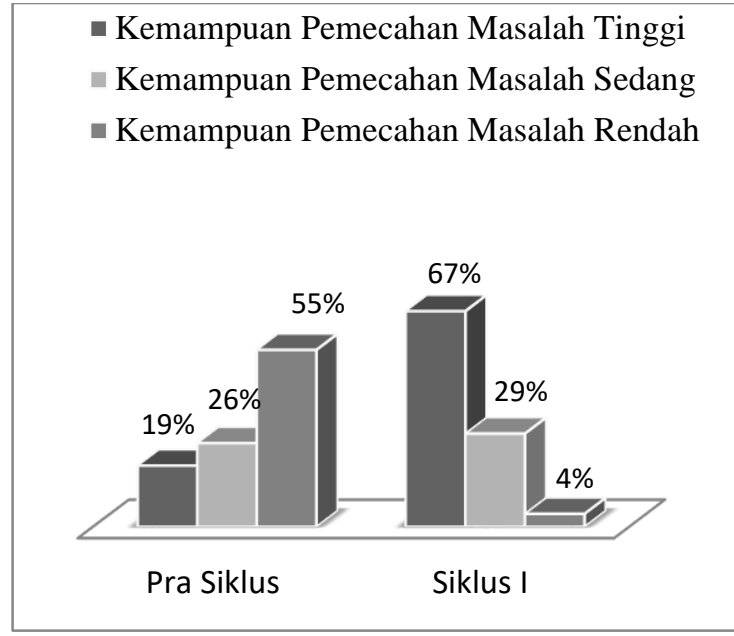

Gambar 4.2 Grafik Peningkatan KemampuanPemecahan Masalah Siswa Siklus I

Hasil pra siklus menunjukkan bahwa persentase jumlah siswa yang berada pada kategori tingkat kemampuan pemecahan masalah tinggi adalah 19\% (15 siswa), tingkat kemampuan pemecahan masalah sedang adalah 26\% (21 siswa), dan tingkat kemampuan pemecahan masalah rendah adalah 55\% (45 siswa). Setelah diberikan tindakan pada siklus I diperoleh persentase siswa siswa pada kategori tingkat kemampuan pemecahan masalah tinggi adalah 67\% (54 siswa), tingkat kemampuan pemecahan masalah sedang adalah 29\% (24 siswa), dan tingkat kemampuan pemecahan masalah rendah adalah 4\% (3 siswa). Terdapat peningkatan pada jumlah siswa pada kategori pemecahan masalah tinggi, akan tetapi angka tersebut belum memenuhi kriteria keberhasilan tindakan dalam penelitian ini. Jumlah minimal siswa yang mencapai kategori pemecahan masalah tinggi adalah $75 \%$, barulah tindakan penelitian ini dapat 
dikatan berhasil. Maka penerapan pendekatan saintifik untuk meningkatkan kemampuan pemecahan masalah siswa pada siklus I belum mencapai target yang diinginkan. Adapun refleksi penerapan pendekatan saintifik pada siklus I yaitu: (a) siswa kurang percaya diri; (b) guru kurang tegas dalam mengarahkan siswa; (c) siswa belum bisa merefleksikan suatu masalah terhadap masalah lain; (d) penerapan pendekatan saintifik untuk meningkatkan kemampuan pemecahan masalah siswa belum terealisasikan dengan baik sesuai yang direncanakan. Masih ada beberapa hal yang perlu dikoreksi dan diperbaiki.

\section{Refleksi Hasil Belajar Afektif Siswa}

Penilaian hasil belajar afektif siswa diperoleh melalui pengamatan yang dilakukan selama proses tindakan dan observasi. Hasil yang diperoleh pada siklus I belum memenuhi kriteria keberhasilan tindakan dalam penelitian ini. Peningkatan hasil belajar afektif siswa pada siklus I dapat dilihat pada grafik berikut:

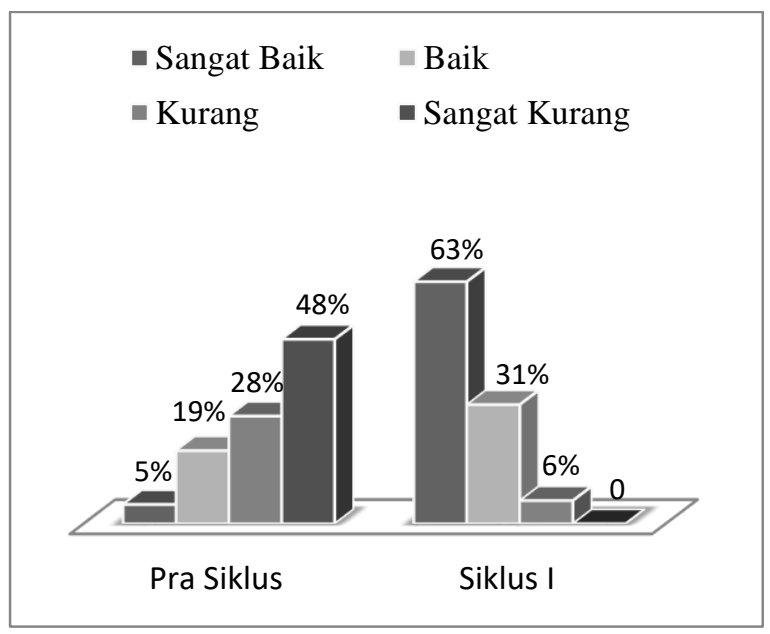

Gambar 4.3 Grafik Peningkatan Hasil Belajar Afektif Siswa Siklus I
Persentase siswa dengan kategori hasil belajar afektif sangat baik adalah 5\% (4 siswa), hasil belajar afektif baik adalah 19\% (15 siswa), hasil belajar afektif kurang adalah 28\% (23 siswa), dan hasil belajar afektif sangat kurang adalah $48 \%$ (39 siswa). Setelah diberikan tindakan pada siklus I diperoleh persentase siswa dengan kategori hasil belajar afektif sangat baik adalah 63\% (51 siswa), hasil belajar afektif baik adalah $31 \%$ (25 siswa), hasil belajar afektif kurang adalah $6 \%$ (5 siswa), dan tidak ada siswa dengan kategori hasil belajar afektif sangat kurang. Terdapat peningkatan pada jumlah siswa pada kategori hasil belajar afektif tinggi, akan tetapi angka tersebut belum memenuhi kriteria keberhasilan tindakan dalam penelitian ini. Jumlah minimal siswa yang mencapai kategori hasil belajar afektif tinggi adalah 75\%, barulah tindakan penelitian ini dapat dikatan berhasil. Maka penerapan pendekatan saintifik untuk meningkatkan hasil belajar afektif siswa pada siklus I belum berhasil. Adapun refleksi penerapan pendekatan saintifik pada siklus I yaitu: (a) siswa kurang disiplin; (b) siswa kurang aktif dalam proses pembelajaran; (c) guru kurang tegas dalam mengarahkan siswa; (d) penerapan pendekatan saintifik untuk meningkatkan hasil belajar afektif siswa belum terealisasikan dengan baik sesuai yang direncanakan. Masih ada beberapa hal yang perlu dikoreksi dan diperbaiki.

Berdasarkan data-data tersebut, maka untuk lebih mengefektifkan peningkatkan hasil belajar matematika dan kemampuan pemecahan masalah siswa perlu dilakukan perbaikan dalam pelaksanaan tindakan penelitian. Maka peneliti merencanakan untuk melanjutkan penelitian ke siklus ke dua dan menjadikan hasil refleksi pada 
siklus I sebagai bahan masukan yang perlu diperhatikan dan diperbaiki pada siklus II.

\section{Siklus II}

a) Perencanaan, penelitian pada siklus II ini adalah lanjutan dari penelitian pada siklus I. Tahap perencanaan pada siklus II disusun berdasarkan hasil refleksi pada siklus I. Berdasarkan hasil refleksi pada siklus I, setiap tahap yang dilaksanakan pada siklus II ini dilakukan perbaikan dan petingkatkan pada halhal yang dianggap menjadi penyebab kurang efektifnya hasil pelaksanaan tindakan yang dilakukan. Permasalahan yang perlu diperbaiki pada siklus ini masih sama pada siklus I, yaitu (1) kemampuan pemecahan masalah siswa rendah, (2) hasil belajar kognitif siswa rendah (3) hasil belajar afektif siswa rendah. Hal ini dikarenakan hasil yang diperoleh pada siklus I belum mencapai kriteria keberhasilan yang telah ditetapkan. Berdasarkan permasalahan yang ada, maka peneliti menyusun rencana pelaksanaan tindakan siklus II untuk meningkatkan hasil belajar matematika dan kemampuan pemecahan masalah siswa dengan penerapan pendekatan saintifik dalam pembelajaran. Adapun rencana pelaksanaan tindakan pada siklus I adalah sebagai berikut: (1) menjabarkan hasil pengamatan awal; (2) membuat rencana pelaksanaan pembelajaran (RPP) yang menggunakan pendekatan saintifik; (3) menyusun bahan ajar; (4) membuat/menyediakan media pembelajaran; (5) membuat pedoman observasi; (6) membuat pedoman wawancara guru dan siswa; (7) membuat instrumen tes untuk mengukur kemampuan pemecahan masalah dan hasil belajar matematika siswa.

b) Pelaksanaan.penelitian tindakan pada siklus II dilaksanakan pada tanggal 28 Februarisampai tanggal 10 Maret 2018 di SMAN 6 TAKALAR. Penelitian pada Siklus II ini dilaksanakan dengan empat kali pertemuan dengan waktu 2x45 menit untuk setiap pertemuan. Pelaksanaan tindakan ini diawali dengan pelatihan penerapan pendekatan saintifik kepada para guru di sekolah tersebut. Pada siklus II diusahakan semaksimal mungkin untuk tidak mengulang kesalahan pada siklus I. Guru diminta lebih tegas dalam mengarahkan dan membimbing siswa, dan setiap siswa diminta untuk aktif dalam pembelajaran. Guru diminta untuk selalu memotivasi siswa sebelum memulai pembelajaran agar siswa lebih semangat dan percaya diri, suasana belajar dibuat seefisien mungkin. Penerapan pendekatan saintifik dalam pembelajaran untuk meningkatkan hasil belajar matematika dan kemampuan pemecahan masalah siswa terdiri dari langkah-langkah sebagai berikut: (1) mengamati, aktivitas belajar yang terjadi pada tahap ini adalah melihat, mengamati, membaca, mendengar, dan menyimak (tanpa dan dengan alat). Pada tahap mengamati di siklus II ini guru bukan hanya menyajikan beberapa data yang berkaitan dengan materi yang akan diajarkan, akan tetapi juga materi-materi dasar yang sangat penting dikuasai siswa agar dapat melaksanakan proses pembelajaran dengan maksimal, termasuk materi sebelumnya yang merupakan materi prasyarat dari materi yang akan dipelajari. Guru mengarahkan siswa agar menggunakan seluruh panca indra yang dimilikinya untuk mengamati informasi-informasi yang terkait dengan materi yang diajarkan. (2) menanya, ertanya merupakan 
salah satu pintu masuk untuk memperoleh pengetahuan. Pada tahap kedua ini siswa dipersilahkan untuk mengajukan pertanyaan dari yang faktual sampai ke yang bersifat hipotesis. Diawali dengan bimbingan dari guru sampai dengan mandiri (menjadi suatu kebiasaan). Pada tahap ini siswa diarahkan untuk mengajukan pertanyaan tentang informasi yang tidak dipahami dari apa yang telah diamati pada tahap sebelumnya atau pertanyaan untuk mendapatkan informasi tambahan. Kompetensi yang dikembangkan adalah kreativitas, rasa ingin tahu, dan kemampuan merumuskan pertanyaan; (3) pengumpulan data, pada tahap ini guru mengarahkan siswa untuk menggali dan mengumpulkan informasi dari berbagai sumber melalui berbagai cara. Pengumpulan data dapat dilakukan melalui eksperimen, membaca sumber lain selain buku teks, mengamati objek, kejadian, aktifitas wawancara dengan narasumber, dan sebagainya. Adapun kompetensi yang diharapkan adalah mengembangkan sikap teliti, jujur, sopan, menghargai pendapat orang lain, kemampuan berkomunikasi, menerapkan kemampuan mengumpulkan berbagai informasi melalui berbagai cara yang dipelajari, mengembangkan kebiasaan belajar dan belajar sepanjang hayat; (4) mengasosiasi, mengasosiasi atau associating dapat pula diartikan menalar atau mengolah informasi. Pada tahap ini guru dan siswa diarahkan untuk aktif dalam proses belajar mengajar, tapi tentunya dalam banyak hal dan situasi siswa harus lebih aktif daripada guru. Siswa diminta untuk bernalar, mengasosiasi, mengolah informasi, dan berpikir kreatif. Berpikir secara logis dan sistematis atas fakta-fakta empris yang dapat diobservasi untuk memperoleh simpulan berupa pengetahuan. Siswa diarahkan untuk memproses informasi yang sudah disimpulkan, baik dari hasil kegiatan pengumpulan data maupun hasil dari kegiatan mengamati dan kegiatan menanya; mengkomunikasikan, ktifitas belajar yang terjadi pada tahap ini adalah siswa menyampaikan hasil pengamatan, kesimpulan berdasarkan hasil analisis secara lisan, tertulis, atau dalam bentuk lainnya. Pada tahap ini guru memberikan kesempatan pada siswa untuk mengkomunikasikan hasil pekerjaan yang telah mereka susun, baik secara bersama-sama dalam kelompok ataupun secara individu. Setelah itu guru juga memberikan klarifikasi agar siswa mengetahui dengan benar apakah jawaban yang telah dikerjakan sudah benar atau ada yang perlu diperbaiki. Kompetensi yang diharapkan dari tahap ini adalah mengembangkan sikap jujur, teliti, toleransi, kemampuan berpikir sistematis, mengungkapkan pendapat dengan singkap dan jelas, dan mengembangkan kemampuan berbahasa yang baik dan benar.

c) Observasi, dilakukan untuk mengamati proses tindakan yang sedang berlangsung. Kegiatan yang dilakukan selama tahap pengamatan dalam penelitian ini meliputi: (1) memantau tindakan pelaksanaan pembelajaran berdasarkan pendekatan saintifik; (2) mengamati dan mencatat hal-hal yang terjadi pada saat proses pembelajaran berlangsung; (3) mengamati aktivitas siswa, baik secara individu ataupun kelompok salama proses pembelajaran berlangsung; (4) Melakukan dokumentasi proses tindakan yang berlangsung. 
d) Refleksi. Refleksi dilakukan dengan mengkaji dan menilai seluruh data yang diperoleh pada setiap tahap yang telah dilakukan sebagai dasar pengukuran keberhasilan penelitian tindakan yang telah dilaksanakan. Data diperoleh dari hasil tes hasil belajar matematika, angket sikap kemampuan pecahan masalah, observasi hasil belajar afektif siswa, dan catatan lapangan pada kegiatan penelitian siklus II yang dijabarkan sebagai berikut.

\section{Refleksi Hasil Belajar Matematika Siswa}

Hasil belajar matematika siswa diperoleh melalui tes formatif. Hasil yang diperoleh pada siklus II telah memenuhi kriteria keberhasilan tindakan penelitian. Peningkatan hasil belajar matematika siswa pada siklus II dapat dilihat pada grafik berikut:

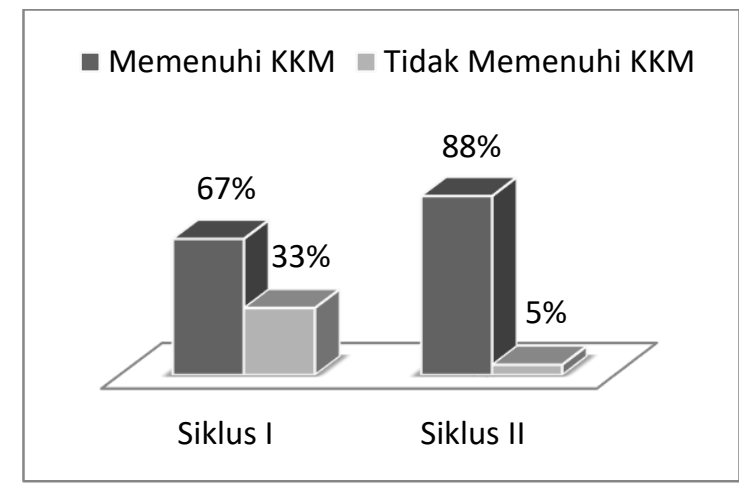

Gambar 4.4 Grafik Peningkatan Hasil Belajar Matematika Siswa Siklus II

Pada siklus I persentase siswa yang memenuhi nilai KKM adalah 67\% (54 siswa) dan siswa yang tidak memenuhi nilai KKM adalah 33\% (27 siswa). Setelah diberikan tindakan pada siklus II diperoleh persentase siswa yang memenuhi nilai KKM adalah 88\% (77 siswa) dan siswa yang tidak memenuhi nilai KKM adalah 5\% (4 siswa). Jumlah siswa yang memenuhi nilai
KKM mencapai kriteria keberhasilan tindakan penelitian yaitu $88 \%$, maka penelitian pada siklus II dinyatakan berhasil. Secara keseluruhan data hasil belajar matematika siswa mulai dari tahap awal penelitian hingga siklus terakhir digambarkan pada grafik berikut:

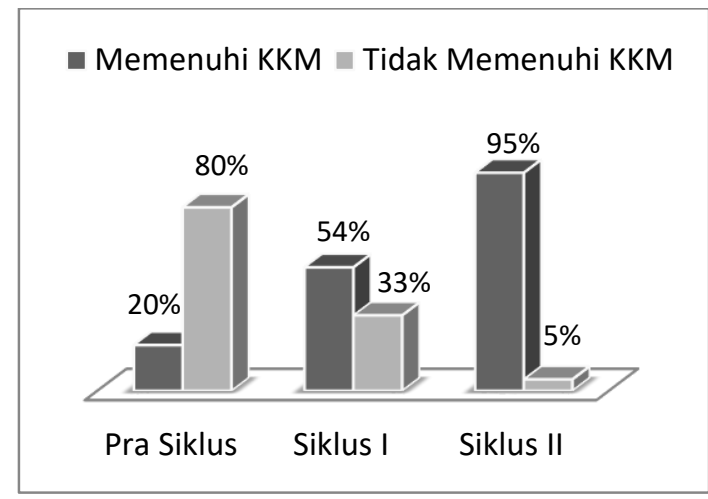

Gambar 4.5 Grafik Peningkatan Hasil Belajar Matematika Siswa SMAN 6 Takalar

\section{Refleksi Hasil Angket Kemampuan Pemecahan Masalah Siswa}

Penilaian kemampuan pemecahan masalah siswa diperoleh melalui angket yang diberikan kepada siswa. Hasil yang diperoleh pada siklus II telah memenuhi kriteria keberhasilan tindakan dalam penelitian ini. Peningkatan kemampuan pemecahan masalah siswa pada siklus II dapat dilihat pada grafik berikut:

- Kemampuan Pemecahan Masalah Tinggi

- Kemampuan Pemecahan Masalah Sedang

- Kemampuan Pemecahan Masalah Rendah

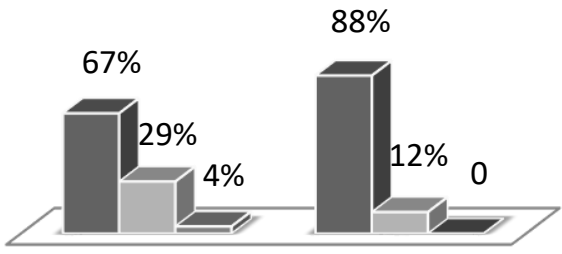

Siklus I

Siklus II

Gambar Tabel 4.6 Grafik Peningkatan Kemampuan Pemecahan Masalah Siswa Siklus II 
Persentase siswa pada kategori tingkat kemampuan pemecahan masalah tinggi adalah 67\% (54 siswa), tingkat kemampuan pemecahan masalah sedang adalah 29\% (24 siswa), dan tingkat kemampuan pemecahan masalah rendah adalah 4\% (3 siswa). Setelah diberikan tindakan pada siklus II diperoleh persentase siswa siswa pada kategori tingkat kemampuan pemecahan masalah tinggi adalah 88\% (71 siswa), tingkat kemampuan pemecahan masalah sedang adalah $12 \%$ (10 siswa), dan tidak ada siswa dengan tingkat kemampuan pemecahan masalah rendah. Jumlah siswa dengan tingkat kemampuan pemecahan masalah tinggi adalah 71 siswa (88\%). Angka ini memenuhi kriteria keberhasilan tindakan, maka penelitian pada siklus II dinyatakan berhasil.

Peningkatan kemampuan pemecahan masalah siswa mulai dari tahap awal penelitian hingga siklus terakhir digambarkan pada grafik berikut:

- Kemampuan Pemecahan Masalah Tinggi

- Kemampuan Pemecahan Masalah Sedang

- Kemampuan Pemecahan Masalah Rendah

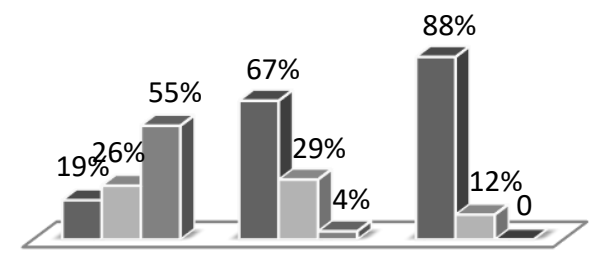

Pra Siklus Siklus I Siklus II

Gambar 4.7 Grafik Peningkatan

Kemampuan Pemecahan Masalah

Siswa SMAN 6 Takalar

\section{Refleksi Hasil Belajar Afektif Siswa}

Penilaian hasil belajar afektif siswa diperoleh melalui pengamatan yang dilakukan selama proses tindakan dan observasi. Data hasil belajar afektif siswa.

Hasil yang diperoleh pada siklus II telah memenuhi kriteria keberhasilan tindakan penelitian. Peningkatan hasil belajar afektif siswa pada siklus II dapat dilihat pada grafik berikut:

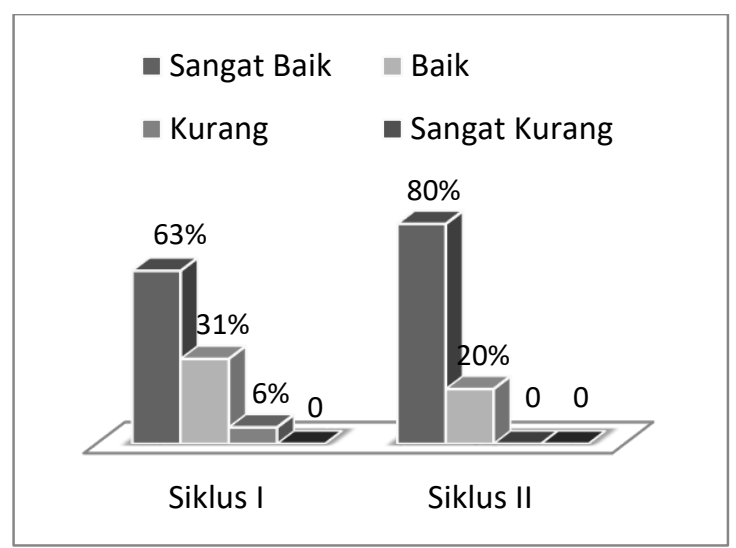

Gambar 4.8 Grafik Peningkatan Hasil Belajar Afektif Siswa Siklus II

Persentase siswa pada siklus I dengan kategori hasil belajar afektif sangat baik adalah 63\% (51 siswa), hasil belajar afektif baik adalah $31 \%$ (25 siswa), hasil belajar afektif kurang adalah 6\% (5 siswa). Setelah diberikan tindakan pada siklus II diperoleh persentase siswa dengan kategori hasil belajar afektif sangat baik adalah 80\% (65 siswa), hasil belajar afektif baik adalah $20 \%$ (16 siswa), dan tidak ada siswa dengan hasil belajar afektif yang kurang ataupun sangat kurang. Jumlah siswa dengan hasil belajar afektif sangat baik mencapai 80\% (65 siswa), maka penelitian ini dinyatakan berhasil. Berdasarkan hasil penelitian pada siklus II, maka dapatdinyatakan bahwa penerapan pendekatan saintifik dapat meningkatkan hasil belajar afektif siswa.

Peningkatan hasil belajar afektif siswa mulai dari tahap awal hingga siklus terakhir digambarkan sebagai berikut: 


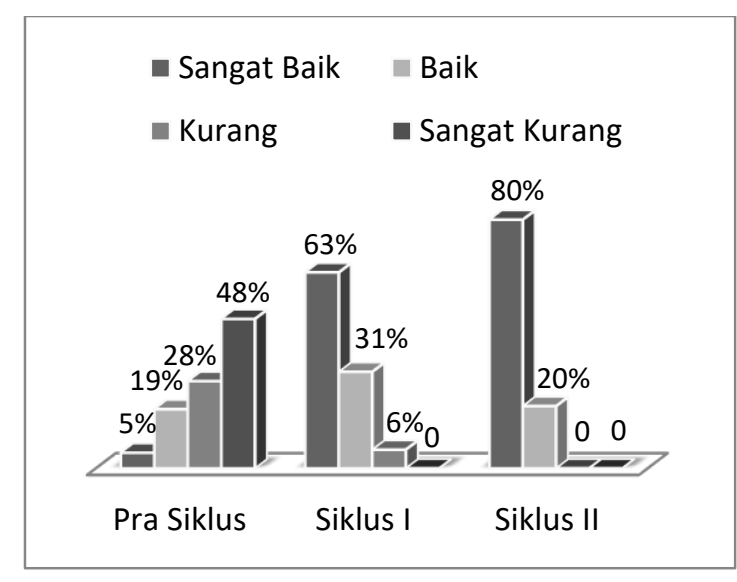

Gambar 4.9 Grafik PeningkatanHasil Belajar Afektif Siswa

\section{KESIMPULAN}

Berdasarkan data-data pada hasil penelitian dan pembahasan, maka disimpulkan bahwa penerapan pendekatan saintifik dapat meningkatkan hasil belajar matematika dan kemampuan pemecahan masalah siswa di SMAN 6 Takalar. Pada pra siklus hanya 20\% siswa yang dapat memenuhi nilai kriteria ketuntasan minimal, setelah siklus terakhir meningkat menjadi $88 \%$. Jumlah siswa yang dengan kemampuan pemecahan masalah tinggi pada pra siklus adalah $19 \%$, setelah siklus terakhir meningkat menjadi $88 \%$. Jumlah siswa dengan hasil belajar afektif kategori sangat baik pada pra siklus adalah 4\%, setelah siklus terakhir meningkat menjadi $80 \%$. Maka hasil penelitian ini sesuai dengan kerangka teoritik yang telah disusun sebelumnya.

\section{DAFTAR PUSTAKA}

Abidin, Yunus. Desain Sistem Pembelajaran dalam Konteks Kuikulum 2013. Bandung: Refika Aditama, 2014.

Agran, Martin. Caryl Blanchard, and Michael Wehmeyer, Increasing the ProblemSolving Skills of Students with Developmental Disabilities Participating in General Education. SAGE Journals. http://journals.sagepub.com/doi/abs/10.1 177/07419325020230050301 (diakses 27 Juli 2018).

Anderson, Larin W., dan David R. Krathwohl, A Taxonomy for Learning Teaching and Assessing. New York: Longman, 2001.

Anderson, Lorin W. dan David R. Krathwohl, Kerangka Landasan untuk Pembelajaran, Pengajaran, dan Asesmen (Revisi Taksonomi Pendidikan Bloom). Yogjakarta: Pustaka Pelajar, 2012.

Arikunto, Suharsimi. Dasar-Dasar Evaluasi Pendidikan: Edisi 2. Jakarta: Bumi Aksara. 2013.

Arikunto, Suharsimi., Suhardjono, dan Supardi, Penelitian Tindakan Kelas. Jakarta: Bumi Aksara, 2010.

Budiyanto, Moch. Agus Krisno., Waluyo, Lud, dan Mokhtar, Ali. Implementasi Pendekatan Saintifik dalam Pembelajaran di Pendidikan Dasar di Malang. Malang: Proceeding Biology Education Confrence. 2016.

Butterworth, Johndan Geoff Thwaites.Thinking Skill; Critical Thinking and Problem Solving. Cambridge: Cambridge University Press.

Chatib, Munif. Gurunya Manusia. Bandung: Kifa Learning, 2013.

Chi, Micheline T. H. dan Robert Glaser. Problem Solving Ability, University of Pittsburgh, http://www.public.asu.edu/ mtchi/papers /ChiGlaser10.pdf (diakses 18 April 2016).

Daryanto. Pendekatan Pembelajaran Saintifik Kurikulum 2013. Yogyakarta: Penerbit Gava Media, 2014.

Direktorat PSMA. Pembelajaran Berbasis Kompetensi Mata Pelajaran dengan Pendekatan Saintifik. Jakarta, 2013.

Djaali. Psikoligi Pendidikan. Jakarta: Bumi Aksara, 2014.

Djamarah, Syaiful Bahri. Psikologi belajar. Jakarta: Rineka Cipta, 2011. 
E.A, Akinmola. Developing Mathematical Problem Solving Ability: A Panacea For A Sustainable Development In The $21^{\text {st }}$ Century. Nigeria: International Journal of Education and Research. 2014.

Gardner, Howard. Muttiple Intelligences; Memaksimalkan Potensi dan Kecerdasan Individu dari Masa Kanak-Kanak Hingga Dewasa. Jakarta: Daras Books, 2013.

Gredler, Margaret E. Learning and Instruction: Terori dan Aplikasi. Jakarta: Kencana, 2011.

Hergenhahn, B.R., dan Matthew H. Olson. Theories of Learning. Jakarta, 2015.

Hosnan, M. Pendekatan Saintifik dan Kontekstual dalam Pembelajaran Abad 21. Jakarta: Ghalia Indonesia, 2014.

Husdarta, JS., dan Yudha M. Saputra, Belajar dan Pembelajaran. Bandung: Alfabeta, 2013.

Huwono, Sitria H. Pengaruh Pendekatan Saintifik terhadap Hasil Belajar Siswa pada Pelajaran Fisika Materi Hukum Gerak Newton Kelas X SMA Negeri 1 Telaga. Gorontalo: UNG, 2014.

Ibrahim, Nurdin. Perspektif Pendidikan Terbuka Jarak Jauh. Jakarta: Bumi Aksara. 2010.

Jamaris, Martini. Orientasi Baru dalam Psikologi Pendidikan. Bogor: Ghalia Indonesia, 2013.

Jordan, Anne., Orison Carlile, dan Anneta Stack. Approacches to Learning: A Guide for Teacher. London: The McGraw-Hill Companies, 2008.

Kite, Janet. Developing a scientific approach in children with learning difficulties in the junior school. https://doi.org/10.1111/ j.1467-9604.1987.tb00291.x (diakses 27 Juli 2018).

Komara, Endang. Belajar dan Pembelajaran Interaktif. Bandung: PT. Refika Aditama, 2014.

Krathwohl, D.R., Bloom, B.S., Masia, B.B., Handbook: Taxonomy of Educational Objectives, The lassification of Educational Goals. New York: David McKay Co., Inc., 1973. http://www.nwlink.com/ doclark/hrd/ bloom.html (diakses 7 Februari 2017).

Madya, Suwarsih. Teori dan Praktik Penelitian Tindakan. Bandung: Alfabeta, 2006.

Marzano, Robert J. dan John S. Kendall.The New Taxonomy of Educational Objectives. Corwin Press, 2001.

Matsui, Tatsunori. Discovery Scientific Approach to Extraction Produce of Educational Procedure of Educational Meaningful Information from Learning History Data. J-STAGE. https://www.jstage.jst.go.jp/ article/pjsai/JSAI02/0/JSAI02_0_217/_ar ticle/-char/ja/ (diakses 27 Juli 2018).

Mayer, Richard E. Cognitive, metacognitive, and motivational aspects of problem solving. Springer Link. https://link.springer.com /article/10.1023/A:1003088013286 (diakses 27 Juli 2018).

Mulyasa,E.Menjadi Guru Profesional. Bandung: PT RemajaRosdakarya, 2008.

Mulyasa, E. Pengembangan dan Implementasi Kurikulum 2013.Bandung: PT. Remaja Rosda karya, 2013.

Muslich, Masnur. KTSP Pembelajaran Berbasis Kompetensi dan Kontekstual. Jakarta: Bumi Aksara, 2009.

OECD, PISA 2015 Reesult, OECD Online. http://www.oecd.org/pisa/ (diakses 20 November 2017).

Ollerton, Mike. Panduan Guru Mengajar Matematika. Jakarta: Erlangga, 2010.

Pragwiradilaga, Dewi Salma. Wawasan Teknologi Pendidikan. Jakarta: Kencana. 2012.

Purwanto, Evaluasi Hasil Belajar. Yogyakarta: Pustaka Pelajar, 2010.

Rusman. Model-Model Pembelajaran; Mengembangkan Profesionalisme Guru. Bandung: PT. Raja Grafindo Persada, 2012.

Saefuddin, Asis dan Ika Berdiati. Pembelajaran Efektif. Bandung: PT. Remaja Rosdakarya, 2014. 
Sitepu, B.P. Penyusunan Buku Pelajaran. Jakarta: Verbum Publishing. 2006.

Springer Link. https://link.springer.com/article/ 10.1023/A:1003088013286 (diakses 27 Juli 2018).

Sriyanto, HJ. Strategi Sukses Menguasai Matematika.Yogyakarta: Percetakan Galang Press, 2007.

Stringer, Ernest T. Action Research. Los Angeles: Sage Publications, 2007.

Sudjana, Nana. Penilaian Hasil Proses Belajar Mengajar. Bandung: PT. Remaja Rosdakarya, 2011.

Sufairoh, Pendekatan Saintifik dan Model Pembelajaran K-13. Malang: Jurnal Pendidikan Profesional. 2016.

Sugiyono, Metode Penelitian Kuantitatif Kualitatif dan $R \& D$. Bandung: Alfabeta. 2011.

Suparman, M. Atwi. Desain Instruksional Modern. Jakarta: Penerbit Erlangga. 2014.

Suriasumantri, Jujun s. Filsafat Ilmu Sebuah Pengantar Populer. Jakarta: Pustaka Sinar Harapan, 2010.

Tolmie, Andy. Understanding Core Skills and Influences in Primary School Science Learning: Taking a Scientific Approach. ERIC. https://eric.ed.gov/?id=ED538487 (diakses 27 Juli 2018).

Trianto. Mendesain Model Pembelajaran Inovatif-Progresif. Rawamangun: 2012.

Undang-Undang Nomor 20 Tahun 2003 Tentang Sistem Pendidikan Nasional Pasal 3.

Uno, Hamzah B., dan Nurdin Mohamad. Belajar dengan Pendekatan PALLKEM. Jakarta: Paragonatama Jaya, 2012.

Wibawa, Basuki. Manajemen Pendidikan Teknologi Kejuruan dan Vokasi. Jakarta: Bumi Aksara, 2017.

Winkel, W.S. Psikologi Pengajaran. Yogyakarta: Sketsa, 2014.

Woods, Donald R. et al. Developing Problem Solving Skills: The McMaster Problem
Solving Program. Journal of Engineering Education: vol.86 issue 2. 2013.

Yaumi, Muhammad., dan Muljono Damopolii, Action Research: Teori, Model, dan Aplikasi. Jakarta: Kencana, 2014 